\title{
Editorial
}

\section{Stem Cells and CAM}

\author{
Edwin L. Cooper \\ Laboratory of Comparative Neuroimmunology, Department of Neurobiology, David Geffen School of Medicine \\ at UCLA, University of California, Los Angeles, Los Angeles, California 90095-1763, USA
}

\section{Stem Cells, Regenerative Medicine and Evolution}

It is no exaggeration that stem cells are a hot topic in the international biomedical arena. In California we are particularly and actually aware of this fact. We started the new year on January 12 with a Stem Cell Technology Conference focusing on senescence. More than a year after California voters elected to give \$3 billion in bonds to fund stem cell research, and with the measure stalled in legal proceedings, professors and researchers met to discuss the proposition and other related concerns at UCLA for a stem cell symposium February 5, 2006 (1). At this event, called 'Stem Cells: Promise and Peril in Regenerative Medicine', several stem cell research experts discussed various topics, all with the goal of illuminating the complex problems of Proposition 71 and its implications. The symposium was organized by the UCLA Center for Society and Genetics, the UCLA Institute for Stem Cell Biology and Medicine and the UCLA School of Law.

Six days later, there was a similar event: the UCLA 10th Annual Health Care Symposium. One of the four speakers was Irving Weissman, MD, director of the Institute of Stem Cell Biology and Regenerative Medicine at Stanford University School of Medicine. For those interested in evolution, Weissman has devoted a good portion of his career to understanding the origins of stem cells in colonial tunicates (2). Then just under a month later, on March 3, there was another 1-day symposium: 'Stem Cells, Pathways and Cancer: From Biology to Therapy'. The two main topics covered aspects of cancer stem cell biology, models and disease and of cancer stem cell pathways as therapeutic targets.

For reprints and all correspondence: Edwin L. Cooper, Distinguished

Professor, Laboratory of Comparative Neuroimmunology, Department of Neurobiology, David Geffen School of Medicine at UCLA, University of California, Los Angeles, Los Angeles, California 90095-1763, USA.

Tel: +1-310-825-9567; Fax: +1-310-825-2224;

E-mail: ecam@mednet.ucla.edu

\section{Stem Cells on CAM: Ears and Teeth on the CAM}

CAM, of course, in the context of $e C A M$ means complementary and alternative medicine. But for the purpose of this editorial, let us engage in a bit of fancy and make a play on words, so that CAM can also mean chorioallantoic membrane. Thinking of CAM in this way conjures up several meanings: (i) stem cells and embryonic development per se; (ii) stem cells and post-embryonic development (i.e. can stem cells rejuvenate or regenerate lost organs, post-embryo, in the adult?); (iii) CAM and stem cells. The first point relates to my masters thesis, in which I isolated the embryonic chick otocysts (the ear primordium of 4-day-old chick embryos) and implanted them on the CAM of older embryos (3). The most difficult part of the experiment was to isolate this tiny primordium under sterile conditions and drop it onto the CAM, a highly vascularized extra-embryonic membrane. Virtually any group of cells, tissues or organs can be readily vascularized and continue to differentiate and develop or, in the case of fully developed structures, enjoy a brief period of maintenance by the blood vessels of the CAM. Of course, the host chick continues its development, making it essential to do serial transfers or, in the case of my embryonic ear, stop the process, open the egg and find a fully differentiated ear with semicircular canals and branches of the two nerves that innervate it. Later, still imbued with a high level of excitement, I suggested the technique to my dear friend Harold C. Slavkin, dean of the USC School of Dentistry. He tried the same procedure with tooth primordia and, of course, achieved a high level of differentiation (4).

\section{Stem Cells and Limb Regeneration}

Still fascinated by multipotent stem cells and what they could do in the right environment, I embarked on a potential $\mathrm{PhD}$ thesis at Brown University (1959-63). Pursuing my research

(C) The Author (2006). Published by Oxford University Press. All rights reserved.

The online version of this article has been published under an open access model. Users are entitled to use, reproduce, disseminate, or display the open access version of this article for non-commercial purposes provided that: the original authorship is properly and fully attributed; the Journal and Oxford University Press are attributed as the original place of publication with the correct citation details given; if an article is subsequently reproduced or disseminated not in its entirety but only in part or as a derivative work this must be clearly indicated. For commercial re-use, please contact journals.permissions@oxfordjournals.org 
with the late Professor R.J. Goss, I learned about the unique regenerative capacities of some urodeles or tailed amphibians (salamanders) capable of regenerating almost any component of their body (5). It has been known for several hundred years that if a salamander's limb is removed, amazing events occur that consist of wound healing and the gradual emergence/appearance of the blastema, a mound or nubbin of stem cells that can re-differentiate and regenerate or refurbish or replace seemingly de novo: new epidermis, connective tissue, muscle, cartilage, bone. I wanted to grow that multipotential blastema, that universal precursor in tissue culture, to see whether I could obtain, in effect, components of the limb. What a feat (6)! With much sorrow, I obtained only minimal but tempting results, a bit of cartilage here and there, just enough to keep me pushing harder to get what I thought would be a limb in culture.

Alas, as a graduate student of only 23 years of age, with no experience in culturing ectothermic vertebrate tissues, there were problems. Evolution and ontogeny were ready for this innovation, as echoed by the reigning stalwarts of developmental biology - notably the late Professor Paul Weiss of Rockefeller University, who strongly encouraged me to tackle the problem (7). Imagine the basic information and understanding we could gain if we were able to cultivate that mound of salamander blastemal cells in and/or around damaged spinal cord of salamanders. Is this not an approach worth trying? Because of the totipotentiality of these cells, it seems reasonable that we could use this salamander system as a model for understanding how adult stem cells may function when confronted with a situation requiring regeneration or replacement or repair of a lost part, either naturally or by means of experimentation. What I tried to do is still relevant and actively pursued in salamanders, i.e. deriving the blastema from regenerating salamander limbs and analysis in vitro $(8,9)$.

\section{CAM and Mammalian Stem Cells}

Now, I would like to consider just a few examples that may be a little more pertinent to $e C A M$, especially in our search for natural products and their effects on stem cells. Roscetti et al. (10) have examined the influence of a methanolic extract of Hypericum perforatum L. and of purified hypericin, which have been comparatively tested on the growth of a human erythroleukemic cell line (K562). This work confirms the interesting role of $H$. perforatum $\mathrm{L}$. in cancer therapy and strongly supports the hypothesis that agents other than hypericin present in the total extract, acting separately or in a combined manner, can impair tumor cell growth. Ferraz et al. (11) screened crude methanolic extracts of six species of Hypericum growing in southern Brazil (Hypericum caprifoliatum Cham. \& Schlecht., Hypericum carinatum Griseb., Hypericum connatum Lam., Hypericum myrianthum Cham. \& Schlecht., Hypericum polyanthemum Klotzsch ex Reichardt and Hypericum ternum A. St. Hil.) for their antiproliferative activity against two cell lines (HT-29 human colon carcinoma cells and H-460 non-small cell lung carcinoma). The most active fractions were the hexane fractions obtained from $H$. caprifoliatum, H. myrianthum and $H$. ternum. Using another product, Gao et al. (12) found that G. psilostachys ethanolic extract inhibits the proliferation of K562 cells and disrupts the normal dynamic of microtubules during mitosis.

Turning to the nervous system, Hostanska et al. (13) have reported the ability of $\mathrm{HP}$ and of polyphenolic procyanidin B2 (PB-2) to inhibit the growth of leukemia K562 and U937 cells, brain glioblastoma cells LN229 and normal human astrocytes. Cytocidal effects of HP and its synergistic cooperation with HY in tumor growth inhibition make the St John's wort an interesting option in cancer warranting further in vitro and in vivo investigation. Finally, Bouhon et al. (14) have examined neural differentiation mouse in embryonic stem cells in chemically defined medium. Neural differentiation in CDM did not occur by a simple default mechanism but was dependent on endogenous FGF signaling, and it could be blocked by adding BMP4 and $\mathrm{LiCl}$ to simulate WNT activation. Neural differentiation was also inhibited by antagonizing endogenous hedgehog activity. Taken together, the profile of gene expression changes seen in CDM cultures recapitulates those seen in the early embryo and is suggestive of common developmental mechanisms.

\section{CAM or CAM?}

So now let us put together the first CAM (chorioallantoic membrane of chick embryos, a place where stem cells can thrive and differentiate) and the blastemal cells (stem cells of adult salamanders) and the newer CAM and stem cells. What is there? Are there opportunities for meshing the two CAMs and stem cells? Or has this been an enthusiastic and joyous reminiscence and an easy play on words? Actually, to mention a few examples, $e C A M$ has already been at the forefront in terms of stem cells from the viewpoint of evolution and primitive cells $(15,16)$, modulatory effects of certain plants $(17,18)$, natural health products (19) and herbs and hemopoietic stem cells (20).

According to Ventura (21),

evidence-based medicine is switching from the analysis of single diseases at a time toward an integrated assessment of a diseased person. Complementary and alternative medicine (CAM) offers multiple holistic approaches, including osteopathy, homeopathy, chiropractic, acupuncture, herbal and energy medicine and meditation, all potentially impacting on major human diseases. It is now becoming evident that acupuncture can modify the expression of different endorphin genes and the expression of genes encoding for crucial transcription factors in cellular homeostasis. Extremely low frequency magnetic fields have been found to prime the commitment to a myocardial lineage in mouse embryonic stem cells, suggesting that magnetic energy may direct stem cell 
differentiation into specific cellular phenotypes without the aid of gene transfer technologies. This finding may pave the way to novel approaches in tissue engineering and regeneration. Different ginseng extracts have been shown to modulate growth and differentiation in pluripotent cells and to exert wound-healing and antitumor effects through opposing activities on the vascular system, prompting the hypothesis that ancient compounds may be the target for new logics in cell therapy. These observations and the subtle entanglement among different CAM systems suggest that CAM modalities may deeply affect both the signaling and transcriptional level of cellular homeostasis. Such a perception holds promises for a new era in CAM, prompting reproducible documentation of biological responses to CAM-related strategies and compounds. To this end, functional genomics and proteomics and the comprehension of the cell signaling networks may substantially contribute to the development of a molecular evidencebased CAM.

\section{References}

1. Tseng W, Taylor S. Delving into stem cells. UCLA Daily Bruin, February 6, 2005.

2. Laird DJ, De Tomaso AW, Weissman IL. Stem cells are units of natural selection in a colonial ascidian. Cell 2005;123:1351-60. Erratum in: Cell 2006; $124: 647-8$

3. Cooper EL. Differentiation of the chick otocyst on the chorioallantoic membrane. Atlanta University: MS Thesis, 1959.

4. Slavkin HC, Bavetta LA. Odontogenesis in vivo and in xenografts on chick chorioallantois-I. Arch Oral Biol 1968;13:145-54.

5. Goss RJ. Adaptive Growth. London: Logos Press Ltd, 1964.

6. Cooper EL. Culture of the regeneration blastema from salamanders. Brown University, 1959, unpublished results.

7. Weiss P. Principles of Development. New York: Henry Holt and Co., 1939.
8. Prince DJ, Carlone RL. Retinoic acid involvement in the reciprocal neurotrophic interactions between newt spinal cord and limb blastemas in vitro. Brain Res Dev Brain Res 2003;140:67-73.

9. Brockes JP, Kumar A. Appendage regeneration in adult vertebrates and implications for regenerative medicine. Science 2005;310:1919-23.

10. Roscetti G, Franzese O, Comandini A, Bonmassar E. Cytotoxic activity of Hypericum perforatum L. on K562 erythroleukemic cells: differential effects between methanolic extract and hypericin. Phytother Res 2004;18:66-72.

11. Ferraz A, Faria DH, Benneti MN, da Rocha AB, Schwartsmann G, Henriques A. von Poser GL. Screening for antiproliferative activity of six southern Brazilian species of Hypericum. Phytomedicine 2005;12: $112-5$.

12. Gao X, Zhang G, Zhou M, Luo D, Li B. Antiproliferative activity of Goldfussia psilostachys ethanolic extract on K562 leukemia cells. Fitoterapia 2004;75:639-44.

13. Hostanska K, Reichling J, Bommer S, Weber M, Saller R. Hyperforin a constituent of St John's wort (Hypericum perforatum L.) extract induces apoptosis by triggering activation of caspases and with hypericin synergistically exerts cytotoxicity towards human malignant cell lines. Eur J Pharm Biopharm 2003;56:121-32.

14. Bouhon IA, Kato H, Chandran S, Allen ND. Neural differentiation of mouse embryonic stem cells in chemically defined medium. Brain Res Bull 2005;68:62-75.

15. Müller WEG, Batel R, Schröder, Müller IM. Traditional and modern biomedical prospecting: part I-the history: sustainable exploitation of biodiversity (sponges and invertebrates) in the Adriatic Sea in Rovinj (Croatia). Evid Based Complement Altern Med 2004;1:71-82.

16. Cooper EL, Schaefer DW. Bone marrow restoration of transplantation immunity in the leopard frog Rana pipiens. Proc Soc Exp Biol Med 1970;135:406-411.

17. Han Y, Son SJ, Akhalaia M, Platonov A, Son HJ, Lee KH, Yun YS, Song JY. Modulation of radiation-induced disturbances of antioxidant defense systems by ginsan. Evid Based Complement Altern Med 2005;2:529-36.

18. Hajtó $\mathrm{T}$, Hostanska $\mathrm{K}$, Berki $\mathrm{T}$, Pálinkás L, Boldizsár, Németh $\mathrm{P}$. Oncopharmacological perspectives of a plant lectin (Viscum album agglutinin-I): overview of recent results from in vitro experiments and in vivo animal models, and their possible relevance for clinical applications. Evid Based Complement Altern Med 2005;2:59-67.

19. Haddad PS, Azar GA, Groom S, Boivin M. Natural health products, modulation of immune function and prevention of chronic diseases. Evid Based Complement Altern Med 2005;2:513-20.

20. Kiyohara H, Matsumoto T, Yamada H. Combination effects of herbs in a multi-herbal formula: expression of juzen-taiho-to's immuno-modulatory activity on the intestinal immune system. Evid Based Complement Altern Med 2004;1:83-91.

21. Ventura C. CAM and cell fate targeting: molecular and energetic insights into cell growth and differentiation. Evid Based Complement Altern Med $2005 ; 2: 277-83$ 


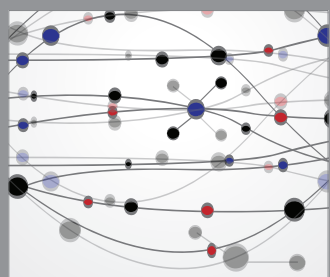

The Scientific World Journal
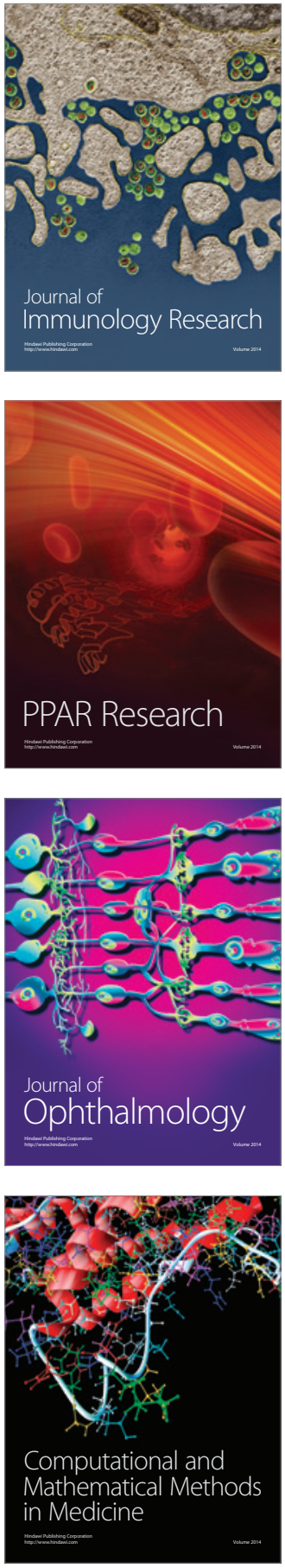

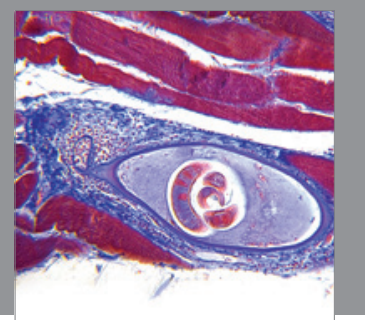

Gastroenterology

Research and Practice
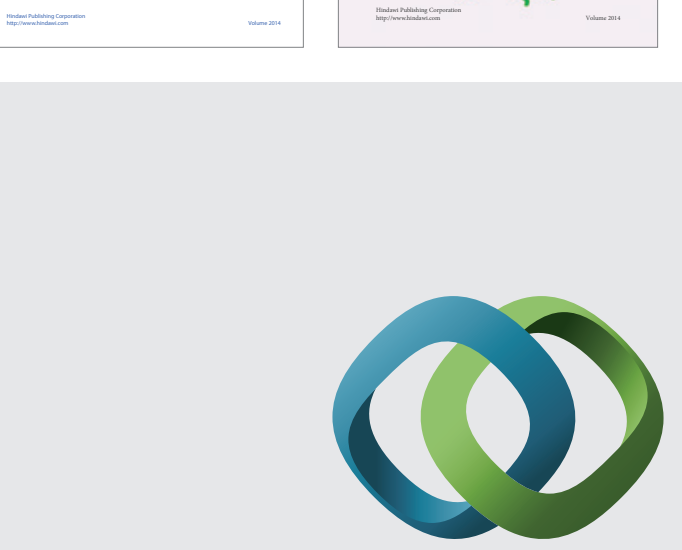

\section{Hindawi}

Submit your manuscripts at

http://www.hindawi.com
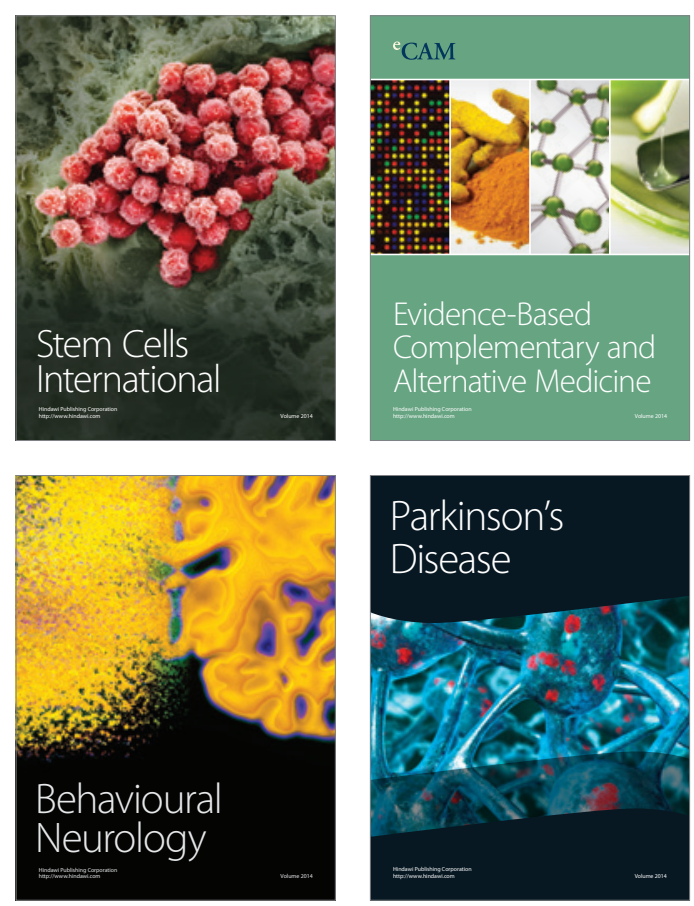

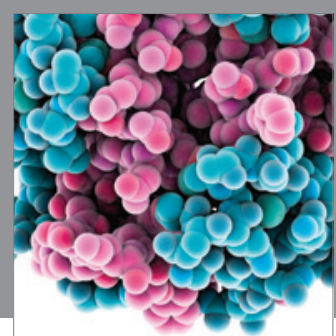

Journal of
Diabetes Research

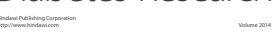

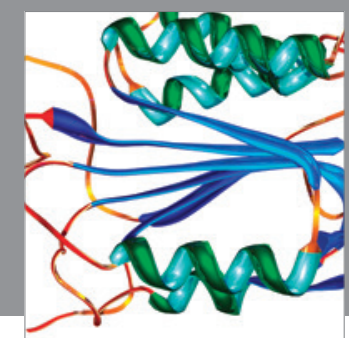

Disease Markers
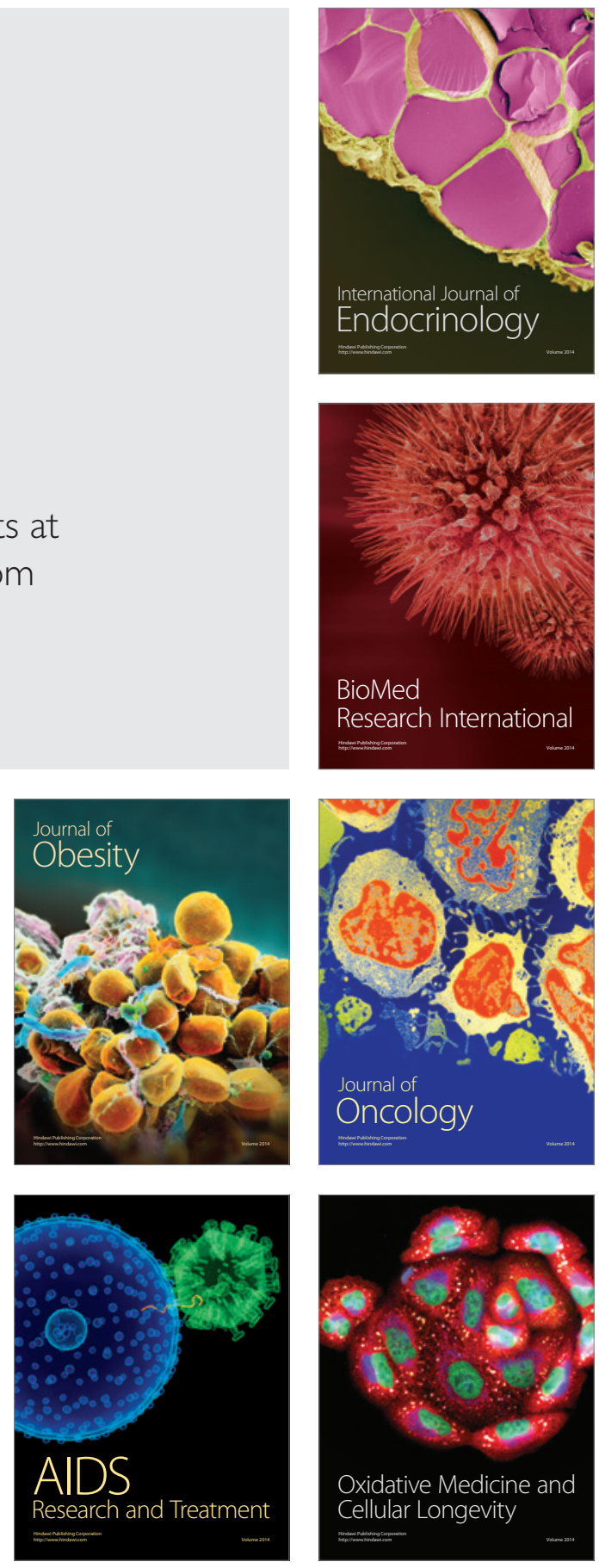